\title{
Witchcraft and transnational social spaces: witchcraft violence, reconciliation and development in South Africa's transition process
}

\author{
Dirk Kohnert *
}

\begin{abstract}
The strange collusion between occult belief systems and different trans-national social networks, embedded in specific transformations of local and global modes of production, results in unique but reinforcing modifications of witchcraft belief, its underlying structures and its impact on the process of democratisation. The amazing range of possible results has been indicated by the analysis of two outstanding examples of witchcraft violence in South Africa in times of transition: in the former homelands of Venda and Lebowa, seemingly 'traditional' elements of witchcraft accusations, mediated by a misguided struggle for liberation, stimulated the sympathetic attention of stakeholders beyond the local setting. On the other hand, the occult base of violence in the Transkei became so blurred by the involvement of 'modern' elements of globalised markets of violence that it was hardly visible any more, although undercover its repressive effects were still very much alive. These different roots of witchcraft violence had serious repercussions on conflict resolution and genuine reconciliation, the base for any sustainable democratisation and development.
\end{abstract}

Résumé: [La Sorcellerie et les espaces sociales transnationales - la sorcellerie, la réconciliation et le développement dans le processus de transition de l'Afrique du Sud] - La collusion étrange entre les systèmes de croyances occultes et les différents réseaux sociaux transnationaux, intégré dans les transformations spécifiques des modes de production locaux et mondiaux, à contribuer au renforcement de croyance de la sorcellerie, ainsi que à la modifications de ses structures sous-jacentes et de son impact sur le processus de démocratisation. L'incroyable éventail de résultats possibles a été indiqué par l'analyse de deux exemples remarquables de la sorcellerie en Afrique du Sud en période de transition : dans les anciens homelands du Venda et Lebowa, des éléments « traditionnels » de l'accusation de sorcellerie, médiée par une lutte malavisée pour la libération, ont stimulé l'attention sympathique des parties prenantes au-delà du cadre local. D'autre part, la base occulte de la violence dans le Transkei est devenue tellement floue, à cause de la participation des éléments «modernes» de la mondialisation des marchés de violence, qu'il était à peine plus visible, bien que ses effets répressifs couvert étaient encore très vivante. Ces différentes racines de violence de la sorcellerie ont eu des répercussions graves sur la résolution des conflits et la réconciliation véritable, qui constituent la base de toute démocratisation et du développement durable.

Keywords: occult belief systems, African religion, development, transition, South Africa, trans-national social networks, reconciliation

\footnotetext{
* Institute of African Affairs, Hamburg. An earlier version of this paper was presented to the conference 'Religion and Social Transformation in South Africa' at the African Studies Centre, University of Cape Town, 18-20 September 2001. Thanks for valuable comments go to the discussants of the paper, Anthony Minnaar and Nokuzola Mndende, as well as to Karola Elwert, Heinz Jockers, Jeff Peires, Kirsten Rüther, Jahsa Wiles, and last, but not least, two anonymous referees. The responsibility for any fallacy of the article remains of course with the author.
} 


\section{Ambiguities of witchcraft and of concepts}

Globalisation and the 'second wind of change' that accelerated democratisation and the transition of the apartheid regime in South Africa in the 1990s led to a reorientation of violent conflicts, away from global to local dimensions. According to the Comaroffs (1999a:279, 284), race and class, the major conflict lines of the apartheid regime, have been overshadowed by cleavages between different age-groups or generations, mediated by gender. Stakeholders of the battle against the apartheid regime, notably at grassroots level, saw themselves increasingly menaced, not by the machinations of colonialism and racism, but by enemies within their own ethnic, village or peer groups. As the enemy from within was held to be particularly vicious and difficult to detect, its actions were especially liable to be explained by reference to supernatural forces. This might be one reason why real and imaginary adversaries of society were increasingly confronted with witchcraft accusations. ${ }^{1}$ Occult belief systems, especially sensitive to changing patterns of social conflict, adapted themselves rapidly to the new situation. Their adherents reacted with new modes of conflict resolution. Witchcraft related violence increased dramatically in South Africa from the middle of the 1980s, but notably in the 1990s in the most impoverished provinces, Limpopo Province and Eastern Cape. The death toll ran into thousands, and reached hitherto unknown dimensions, for example in the former homelands of Lebowa, Gazankulu and Venda, or in the districts of Tsolo and Qumbu (Transkei). The impact could be felt not just within the microcosmos of village communities, but also at meso and macro level of society. Apart from the immeasurable harm that 'witchcraft violence' inflicted on the individuals and families concerned, it destabilised the social, economic and

\footnotetext{
${ }^{1}$. For a detailed discussion of definitions and concepts of witchcraft, sorcery and magic in different local contexts, as well as on the limitations and fallacies of general delimitations of witchcraft, notably in the African context, and finally on the ambiguities of transfer of Eurocentric concepts of magic and witchcraft in African societies, see Geschiere 1997:12-15, 215-224; Kohnert 1996. In most South African provinces, 'witchcraft' is widely known either under the English term or by the name of baloyi, a Sotho expression, for which there exists no accurate English word, but which corresponds most closely to the European connotation of 'witchcraft'. Among the Mpondo of the Transkei, witchcraft is known either by the English term or by Oqhira (in Mpondo) or ubugqwirha (in Xhosa).
} 
political setting of a whole region, seriously endangered the state monopoly of force, and undermined the legitimacy of the new post-apartheid government in the eyes of the local population. Public as well as civic institutions were at pains to stop the violence, but apparently with limited success. 'Witchcraft violence', a highly ambiguous expression, which will be explained in detail below, continued. In September 1998 the Commission of Gender Equality (CGE) recommended that witchcraft-related violence should be declared a national priority crime in order to give it both the prominence in crime prevention it deserved and specific budget allocations. ${ }^{2}$

Scholarly analyses abound on the modernity of witchcraft in African societies, stressing its influence on current power relations, politics and development. ${ }^{3}$ However, one of the puzzling questions still to be solved concerns the ambiguous nature of witchcraft, ${ }^{4}$ which makes it difficult to predict the impact of occult belief systems in Africa in general, and of witchcraft violence in particular. The intriguing contradiction between the emancipative versus repressive impetus of different anti-witchcraft movements in the view of the stakeholders, as well as its significance for lasting reconciliation, are at the centre of the following analysis. Much of the ambiguity of occult belief systems may be explained by reference to the concept of Transnational Social Spaces (TSS; cf. Pries 1999; Sassen 1999), complemented by analysis of the articulation between witchcraft accusations and the modes of production in which they are embedded (cf. Kohnert 1983). More often than not, the change over time of content and meaning of witchcraft accusations appears to go unnoticed by the population and researchers alike, because it is disguised by continuity in its outward appearance.

\footnotetext{
${ }^{2}$. In 2000 the South African Police Service (SAPS) consolidated the long list of priority crimes into three basic categories: (a) organised and trans-national crimes, (b) violent crimes (like armed robbery and murder), (c) crimes against women and children (including witchcraft violence; (personal communication, A. Minnaar). Already in 1996, witchcraft-related murder had been declared the number one priority crime in the Northern Province; the number one priority crime in Eastern Cape was identified as 'stock theft' (cf. Minnaar 1999: 25).

3 . For a comprehensive review of the state of the art, see Geschiere 1997, 2000; Faure 2000; Kohnert 1996; Niehaus 2001.

4. See Geschiere 2000: 28: 'Presque partout en Afrique, ces forces occultes sont considérées comme un mal primordial. Mais un autre principe général veut que ces forces puissent être canalisées et utilisées à fin constructives.' See also Geschiere 1997: 9-12, 23, 233; Niehaus 2001: 192).
} 
Due to the process of globalisation, the conventional comparative analysis of different states, or geographical and social entities, no longer suffices to explain the interlacing coherence networks' (Norbert Elias, quoted in Pries 1999: 3), constituting new social facts that emerged outside the unit of analysis of national societies or their local representations. Rather than simple comparative studies, simultaneous multi-site research with due regard to trans-local social spaces would be required. In fact, this constitutes a basic insight into the TSS concept and the general methodological working hypothesis of this paper to be tested in the subsequent case studies (cf. Kohnert 1983: Pries 1999). The profound links between witchcraft and modernity, promoted by globalisation, such as the 'odd complicity' between occult belief systems in sub-Saharan Africa (SSA) and recent transformations of the world market, have already been aptly analysed by Geschiere (1997), the Comaroffs (1999a) and others. ${ }^{5}$ These authors stress the dialectical interplay between the local and the global as heuristic dimensions of analysis. Nevertheless, either the state or the nation, be it even in its magic representation as an 'alien-nation' of zombies or immigrants (cf. Comaroff et Comaroff 1999b: 21), remain an important methodological point of reference for analysis. ${ }^{6}$ Certainly, the trans-local dimension of occult belief systems has also been noted by different authors but rather perceived as a heuristic concept, to illuminate the linkage of local and global phenomena in its historical setting rather than reflecting empirical facts (cf. Comaroff et Comaroff 1999a: 294). Yet many stakeholders are caught directly in trans-local social networks, which apparently exert an ever-increasing impact on modern structures of witchcraft accusations. These different roots of witchcraft violence had serious repercussions on conflict resolution, as will be demonstrated below.

\footnotetext{
5 . It goes without saying that 'modern' witchcraft accusations are often rooted in the colonial or even precolonial past, whereas 'tradition' has been invented time and again, by old and new authorities alike, e.g. to legitimise a change of power relations (see Comaroff \& Comaroff 1999a; Geschiere 1997:6-9, 2000).

6. See Geschiere 1997: 6-8: '... nearly everywhere on the continent the state and politics seem to be a true breeding ground for modern transformations of witchcraft and sorcery'. Nevertheless, Comaroff \& Comaroff (1999a), Geschiere and others underline the surprising capacity of the customary discourse on witchcraft to link the 'global' and the 'local', or micro and macro levels of popular interpretations of transition in modern Africa: 'Le marché mondial représente, comme la sorcellerie, une brèche dangereuse dans la clôture de la communauté locale.' (Geschiere 2000: 26).
} 


\section{Witchcraft violence and expansion of trans-national social spaces}

Despite undisputed common denominators concerning the modernity of witchcraft, the international discourse on the meaning of magic and witchcraft in Africa remains controversial, not just between academics and stakeholders, or along the socio-cultural divide between Western and African experts, but also between antagonistic schools of thought within Western social science. ${ }^{7}$ African scholars, religious leaders and healers, as well as politicians, maintain that they, with other Africans, share a common ground of 'basics' of occult belief, i.e. that witchcraft is a reality, which is to be considered as an integral part of African culture, and they act accordingly. Therefore, analytical concepts of witchcraft should take this emic view on the subject into account. 'Witchcraft violence', the central theme of this article, considers both the emic view of serious harm and violence, inflicted by (imaginary or real) witches on innocent citizens and all forms of violence applied against people accused of witchcraft. The former can be at least as fatal as the latter in the view of the stakeholders. Anyway, most Africans consider witchcraft as an evil, sometimes satanic force (cf. Geschiere 1997:12-5, 215-24; Meyer 1999).

Local manifestations of trans-national social challenges, like globalised concepts of democratisation, of aid and human rights policies, markets of violence, arms and drugs trafficking, or the crusade of new charismatic churches against the evil, are major factors in explaining the virulence of modern African anti-witchcraft movements (cf. Kohnert 2002). Furthermore, I want to test in this article the hypothesis that the degree and manner of involvement of stakeholders in trans-local social spaces may determine to a considerable extent whether the intrinsic motivation for witchcraft eradication movements

\footnotetext{
7. The change in the European conception of African magic over time is just one indicator of this controversy (see Pels 1998).

8. See CGE 1999:59; Ralushai et al. 1996: 64. The Ralushai Commission, composed of an interdisciplinary team of scientists, government officials and representatives of religious denominations, investigated the incidence of witchcraft violence in the former homelands (1987-1994), at the request of the government of the Northern Province of South Africa. It arrived at the conclusion: 'From the above statements, it becomes very clear that no one can now argue that witchcraft is a myth which can only exist in the minds of the ignorant' '... Belief in witchcraft and related practices form part of a basic cultural, traditional and customary principle of Africans in South Africa, and Africa as a whole.' (Ralushai 1996: 56-7). The inside perception of stakeholders or researchers is called the emic view; the outside perspective the etic view.
} 
has either emancipatory or repressive inclinations. In short, does the relative inward orientation of stakeholders in Limpopo Province explain the genuine impetus for liberation in modern witchcraft accusations? Does, on the other hand, the culture of violence and resistance in the Transkei, promoted by historical links to trans-national social spaces, explain the repressive tendencies of witchcraft violence? The answer to these questions is considered to be crucial for evaluating the legitimacy of witchcraft violence in the emic view and, closely connected with these issues, for assessing the chances of sustainable efforts for reconciliation, democratisation and economic development.

\section{Liberation by witchcraft eradication? Inward orientation and witchcraft violence in Limpopo Province}

The Northern Province of South Africa, renamed Limpopo Province in February 2002, constitutes one of the nine provinces created by the post-apartheid regime immediately after the 1994 democratic elections. It is one of the poorest regions of the country and incorporates the three former self-governing 'homelands' Lebowa, Gazankulu and Venda. Despite lacking economic development, poverty and growing inequality, the official image of the region - as proudly documented on billboards along the major roads at the southern frontiers of the province - is one of tranquillity where man and nature are still at peace. Like any other remote region of South Africa, it has a long historical tradition of exploitation of local inhabitants by outsiders, and of seasonal or semi-permanent migration. Although significant linkages to the urban or industrialised centres are indisputable, there had been, up to the end of the apartheid regime, a remarkable absence of strong migrant, civic or underground informal political organisation, compared with other provinces (Delius 1997: 219-20). In the Weberian sense of an ideal type, we will refer to this situation as relatively strong inward orientation, with no significant differentiation between local and social spaces. Different social spheres and social classes do exist, but are more often than not closely linked to each other within the same social space of shared worldviews, religious and cultural practices (cf. Pries 1999: 2-8). Growing witchcraft violence in the Limpopo Province during the transition process, notably since 
the early 1990s, drew considerable attention from the media, the state and civil society (cf. CGE 1998; Ralushai et al. 1996). In addition, it was thoroughly investigated by different scholars, who offered a broad spectrum of explanations which were not always compatible. ${ }^{9}$ For the sake of argument, it will suffice to highlight only those aspects and differences, which are relevant in relation to our above hypotheses.

Delius concentrated on a case study of reconstruction and political resistance in Sekhukhuneland (in the former 'homeland' of Lebowa, Northern Province). This poorly developed rural area had a long tradition of revolt and underdevelopment, but to characterise the population as a backward peasant society would be misleading. It would obscure the vital role of income from urban employment and the importance of resources, networks and experiences spanning the city and the countryside. Already by the 1930s, the remittances of migrant workers were considered to be the lifeblood of the local society. From the late 1930s the policy of 'trust land', euphemistically labelled 'development' by representatives of apartheid, was regarded by most stakeholders as a poorly disguised attempt to force them into political and economic subordination (Delius 1997: 216-20). Structural marginalisation triggered the first revolt in 1958. From the late 1970s, the flow of remittances faltered as unemployment grew; female migration became increasingly common, and the number of female-headed households expanded. Cleavages between gender and generation widened, and the relationship between traditional chiefs and their subjects soured because of an assumed collaboration of the former with the apartheid regime. This was a social climate in which fears about witches flourished, nourished by rapidly expanding charismatic churches, like the Zionist Christian Church, which offered sanctuary and support against the Evil, incorporated by the witches (Delius 1997: 218-9; Kohnert 2002). Resistance again became more articulated during the 1980s and climaxed in the second open Sekhukhuneland revolt in 1986. Since the unbanning of the ANC, and during the subsequent ANC election campaign in the Northern Transvaal, the issue of witchcraft - which had been festering since 1986 - again came to the surface with a violence never experienced before. Although the content of witchcraft accusation was still basically shaped by tensions between neighbours and kin, and by generation and gender-

\footnotetext{
${ }^{9}$. See Delius 1997; Kessel 1993; Minnaar 1999; Niehaus 1998, 2001, 2002; Stadler 1996.
} 
based conflicts, it acquired a new direction and applied new methods, both strongly influenced by the nationwide discourse of the anti-apartheid struggle. In the first four months of 1994 for example, elements within the youth, usually acting with wider support in their communities, accused more than 70 people of witchcraft and killed them.

\begin{abstract}
'There were some continuities with earlier struggles, most notably in the role of ANC symbols and sympathizers. But, while cadres and migrants played some part, the profound changes which had taken place in the nature of the society and its context moulded a very different pattern of politics. The uprising was led by youth organizations ... Their actions were motivated by the belief that it was their duty to build a new social and moral order purified of the corrupting influence of the agents and institutions of apartheid. But, in the absence of strong migrant, civic or underground organization, they failed to weld together the broadly based alliance ... and their actions increasingly took the form of a general revolt against all forms of local authority. The youth saw themselves as ushering in a new world. But their ideology and actions ... were shaped by an eclectic synthesis of the beliefs which prevailed within local-level society ...In a minority of settlements, witches were identified as the main impediments to harmony and progress, and were burned.' (Delius 1997: 219-20).
\end{abstract}

Later on, the veil of legitimacy of these witch purging movements vanished, as villagers became increasingly upset by the disregard for established procedures and by the brutal actions of the political activists (Delius 1997: 220). Nevertheless, the movement had its spread effects. The vision of the comrades in Sekhukhuneland on millennial liberation, brought about by fighting apartheid and witchcraft, was certainly shared by young ANC activist in the former homeland of Venda, another area of rural Northern Province, investigated among others by Minnaar (1999) and Ralushai et al. (1996). Starting already with the implementation of the betterment schemes in the 1960s, but notably since 1989 , there had been a dramatic resurgence of witch-hunts which started with the release of political prisoners in 1989 and culminated in a veritable witch craze short after the release of Nelson Mandela in February 1990. The upsurge in witchcraft cases was interlinked with the witch-hunts in Lebowa and Gazankulu during the 1980s which eventually spread to Venda. At the first culmination point in March 1990 a climate of terror reigned, where anyone accused of being a witch was killed on the spot; in some villages, up to five accused witches were burnt each night (Minnaar et al. 1991: 53).

Prior to the 1980s, witches convicted by the village courts were mostly exiled. Now things had changed. Youth activist killed them spontaneously, without the aid of traditional 
authorities or diviners, ${ }^{10}$ as they suspected the chiefs' courts of bias in favour of the apartheid regime. ANC sympathisers thought that the time had come to uproot traditional beliefs, and all relicts and collaborators of apartheid, in a general struggle to eradicate backwardness once and for all, a stance seemingly supported by the South African Youth Congress (SAYCO). Unfortunately, the young comrades in Venda utterly misunderstood the Marxist jargon of the ANC, in equating backwardness and evil with witchcraft. On their way to confront alleged witches, the young witch-hunters used political slogans, waved banners and flags of political groups, and sometimes even sang political freedom songs, adapting the wording especially to witch-hunting. 'Ironically, while attempting to eradicate superstitious beliefs, the youth, in fact, sustained them by focusing on the assumed witches rather than on those reinforcing the belief in witchcraft.' (Minnaar et al. 1991: 55-6; cf. Ralushai et al. 1996: 216).

Whereas in the early 1990s, the young ANC comrades gained legitimacy at the local level by sidelining local chiefs in their pursuit of witches, the construction of the postapartheid regime brought another change in conflict lines at the local level. During the second culmination of witch purging in Lebowa and Venda, in the period before the April 1994 elections, the comrades became increasingly opposed to their seniors in the party ranks, the regional and national ANC leaders, who strongly condemned witchcraft violence. In search for new allies, they fell back on a qualified collaboration with traditional leaders, who had been assigned a new (restricted) role within the Mbeki government's Local Government Reform. Like the chiefs, the comrades were more concerned with gaining or maintaining local political power than with complying with the demands of the outside world (cf. Niehaus 1998:115). ${ }^{11}$

${ }^{10}$. Traditional African healers are usually categorised in two ways. First, the diviners or spirit mediators and healers (male and female; e. g. isangoma in Zulu, amagqira in Pondo, nga ka in North Sotho; mungome in Venda), who communicate with the ancestors, possess paranormal capabilities, and perform a variety of important religious, social and political roles, like divination, healing, protection, and last not least the detection of witches. Second, the herbalist and healer (inyanga in Zulu). The capability to 'smell out' witches has been ascribed by most stakeholders to the diviner, who is known in most parts of South Africa under the heading of the Zulu word sangoma. According to estimates of the Institute of Natural Resources, Pietermaritzburg, about 200,000 sangomas or traditional healers were practising in South Africa in 1997, and on average $84 \%$ of South Africans consult a sangoma at least three times a year (see Lambrecht 2000).

11. Against the background of his own field study in Green Valley, yet another part of the Transvaal lowveld (Lebowa, Northern Province), Niehaus (2001, 2002) however cautioned against a deterministic functional interpretation of witchcraft accusations. 
In either period, a strong generation and gender bias of witchcraft accusations were evident. Thus, most victims killed in Northern Province between April 1994 and April 1995 were above 60 years, about two-thirds of the 228 victims were women, and the perpetrators, who burned, stoned or 'necklaced' the assumed witches were overwhelmingly young men between 16 and 25 years. ${ }^{12}$ Finally, although there was an indisputable gender bias in witchcraft violence in the Limpopo Province, it was apparently not as marked as in Eastern Cape, or during the witch craze of medieval Europe. The strength of the gender bias to the detriment of women may have been linked to the emancipative or repressive impetus of witchcraft accusations: in Limpopo Province, where the accusers had considerable backing from the local population, $40-60 \%$ of the victims were men. In the Transkei, where witchcraft violence had strong repressive tendencies, more than $80 \%$ of the victims were women, for reasons explained in the following section. ${ }^{13}$

\section{Oppression by witchcraft accusations? Culture of resistance and violence promoted by trans-local social spaces in Eastern Cape}

The violent conflicts in Tsolo and Qumbu districts of Eastern Cape in the 1990s, which took the lives of well over 1.000 people, have been characterised by Anthony Minnaar (1998: 7) as 'South Africa's most under-reported war zone'. The Kroon Commission of Inquiry of $1995,{ }^{14}$ as well as the Human Rights Committee $(1996,1997)$ investigated the clashes, and there are enlightening analyses of its historical roots and impact by Beinart (1987a, 1987b), Minnaar (1998), and Peires (1994, 1999). Yet its entire dimension remained blurred. This holds notably for the occult aspect of the conflict. Though certainly of secondary importance in relation to other factors of violence, witchcraft-related violence

\footnotetext{
12. See Minnaar 1999: 8-9. The numbers refer only to killings recorded by the police; the actual incidence may be considerably higher. Witchcraft violence in remote rural areas was often not reported to the police, as in many cases the villagers were behind the perpetrators, whom they regarded as heroes (Minnaar 1999: 13).

13. See Niehaus 2001:17, fn.14. Different reasons have been offered by various authors to explain this apparent gender-bias in Africa, which differs significantly from that in Europe and has been reconsidered elsewhere. See also Kohnert 1983: 8-11, 25-27, 29-35; Kohnert 1996: 1349).

14. The official Kroon Commission of Inquiry, established in February 1995 by Eastern Cape premier Raymond Mhlaba, wrote a report which was still treated as confidential in April 2002. The two reports of the Human Rights Committee (HRC 1996; 1997) have been published, but hardly noticed by the general public.
} 
in Eastern Cape during the 1990s may have had similar dimensions to that of witchcraft violence in Limpopo Province. ${ }^{15}$

The districts of Tsolo and Qumbu, and the surrounding area of Pondoland, ${ }^{16}$ have been regarded as hotbeds of resistance since the advent of colonial rule. Its remarkable struggle against outside oppression had surprisingly strong historical roots in trans-national religious and social networks and was characterised by long-standing tough inter-group hostilities. In pre-colonial times the area had been valued because of its rich development potential, inhabited by a proud and independent people (Beinart, 1987a: 112-3). By the time of the Transkei Rebellion of 1880 against colonial domination and the introduction of a hut tax register, resented as potential threat notably by the African population of Tsolo and Qumbu, the area had already shown its determination to withstand oppression. The villagers detested not only the implicit payment of taxes according to the number of wives (huts) per household head, but also the use of the taxation system as a pretext to confiscate land and cattle or to deny bride price claims. Last not least the tax register provided intimate knowledge on the taxpayers, which in the local view could be used by colonial administrators, who were believed to collude with witches and sorcerers, to inflict serious harm. A Tsolo-based missionary had as early as 1880 the impression that witchcraft accusations induced by colonial oppression grew to epidemic proportions. ${ }^{17}$

When the transformation of the political economy of the colonial Cape Province in the wake of the discovery of gold and diamonds resulted in pressure for cheap migrant labour from rural areas like Tsolo and Qumbu, the local political and economic crisis in a hitherto affluent peasant society was further accentuated. Resistance to repression was fuelled by new trans-national religious networks. The 'Ethiopians', an independent African church, broke away from the conventional local Presbyterian Church, and spearheaded the protest

\footnotetext{
15 . Field studies on the political economy of the occult dimension of the Tsolo \& Qumbu conflicts were conducted in 2001/02 within the framework of a Special Research Programme (SFB 520) of the University of Hamburg, Germany, funded by the DFG.

16. The districts of Tsolo and Qumbu were renamed and combined into 'Mhlontlo Municipal district' in 2001. However, as the inhabitants of Pondoland (and most parts of East Griqualand in which Tsolo and Qumbu are situated) still use the old designation, the traditional names are retained in this article.

17. See Redding 1996a: 257: 'People's survival, as they saw it, may have depended upon the removal of a state that was prohibiting them from discovering and punishing all the "evilly disposed" people.' Apparently, it was not the individual European, who was suspected of sorcery or witchcraft, but the colonial administration as such, reinforced by collaborating local chiefs with renowned occult power.
} 
movement against the local representatives of the colonial state, much to the discontent of the established mission churches, state representatives and Cape politicians. ${ }^{18}$ Those who broke away from the established churches rejected progressive controls. They looked for independent African churches, recognising and integrating fundamental elements of African culture, like the belief in witchcraft. In this respect, the 'Ethiopians' shared common interests with the modern charismatic and Pentecostal churches actively exploiting the belief in witchcraft in the Transkei and elsewhere nowadays (cf. Meyer 1999; Wiles 2002). About a decade later, in 1922, when drought hit the area and the severe economic pressure of the post-war economic crisis was felt in South Africa's countryside, popular unrest spread again from the Hlubi community of Qumbu. What first appeared to be a mere boycott of trading stores and schools, and passive resistance to taxation and registration, developed into a generalised resistance movement against the state with a remarkable gender bias, which awaits to be explored in more detail. This conflict spread to Herschel district, which had a considerable immigrant Hlubi population. The leaders of this popular protest movement were educated Christian Hlubi women, calling themselves Amafelandawonye or Amafela, the 'die-hards', later instrumentalised by Wellington Buthelezi in his attack against the local ANC branch in 1928/9 (cf. Beinart 1987b: 255). Leadership and core support for this movement came from women's church unions, established around the turn of the previous century, which provided for religious and considerable economic independence for women (cf. Beinart 1987b: 238-9), much to the chagrin of their husbands or friends. ${ }^{19}$ In the 1950s, the Makhuluspan disturbances, linked

\footnotetext{
18. The movement contained not only a strong undercurrent of anti-colonial feelings but also antagonistic faction fighting for power within the local traditional and religious communities. According to the magistrate in Qumbu at that time, the Ethiopians 'appear to be entirely poisoned by American ideas instilled into them by the Ethiopian section'. The 'Ethiopianism', followed by the Qumbu Presbyterians, shared many of the broader ideas of the Ethiopian movement, which the magistrate labelled as 'American', as it was backed by Afro-American missionaries looking for their African roots, independence and indigenous forms of Christian belief. (Beinart 1987a: 116-7; 1987b: 251). In 1912 and 1913 a 'wave of lawlessness' swept over Qumbu district, which the state observed with special concern, as tensions had been simmering since the district had been conquered by the Cape Colony in the 1870s (Beinart 1987a: 106). To quell the conflict Cape Mounted Riflemen had to be called in. They withdrew in September 1912 after execution of their appeasement operation, except for a small contingent left at Qumbu village.

19. Comparative historical evidence from West African countries suggests that such gender conflicts, caused by the growing economic independence of women, are especially prone to induce radical antiwitchcraft movements. They were either initiated by men with a repressive impetus against women, as in the case of the ndako gboya of the Nupe (Northern Nigeria, see Kohnert 1983), or initiated by women, to defend
} 
to an anti-theft movement with strong political overtones, caused considerable tensions with state authorities in Tsolo and Qumbu, creating a kind of second-tier local structure to bypass formal administration and justice, which were considered by most villagers to be ineffective and biased in favour of rich cattle owners and traditional chiefs. The Makhuluspan was quelled in 1961, alongside other protest movements linked to the Mpondoland revolt in $1961 .^{20}$

During the transition period of the 1990s, the administration and criminal justice system in this part of the Transkei were on the verge of collapse, with all the possible negative effects that could have for the entire province (cf. Minnaar 1998). As already noted, the area had never been as remote and isolated as it was characterised in newspaper reports of that time but had from the start been deeply entrenched in regional, national, and even global strategies for power and influence. Major factors of the trans-local expansion of social spaces, as defined by Ludger Pries (1999), ${ }^{21}$ have had a decisive impact and should be considered in the analysis of this peculiar local transition process of the apartheid regime. Almost all the major sources of present day conflicts were already present in status nascendi some 80 years ago: cleavages between age, ethnic, social, religious and gender groups within the rural communities, accentuated by outside interference by migrants, missionaries, state representatives and politicians who tried to instrumentalise the conflicts for their own ends. Last not least, a new economic outlook, inspiring or frightening, depending on the conflicting groups to which the stakeholders belonged, caused by the development of new modes of production, the changing demand of the national and world markets, as delimitated above, had its impact on the consolidation of occult belief systems. It would be difficult, if not grossly misleading, to try to understand the religious and

their newly acquired independence against the paternalism of the regulos and the post-colonial state, like the njang-njang movement in Guinea Bissau (Kohnert 1988).

20. See Peires 1994: 10-8; 1999: 3, and the TRC hearings on human rights violations and the battle of freedom by the Mpondo in 1960 (massacre of Ngquza hill; http://www.doj.gov.za/trc/hrvtrans/Lusiki/ gxabu.htm) for a more detailed account.

21. See Pries 1999: 2. A high incidence of semi-permanent or seasonal labour migration causes growing economic, social and individual emotional insecurity. Work trajectories and life-cycles, as well as subjective life planning and biographical projects of groups of people, span between different local places. Overall insecurity causes growing cleavages between residents' and migrants' primary means of social and economic positioning, values and orientations. These cleavages have strong gender-specific repercussions, notably on witchcraft accusations and witchcraft-related violence against elderly women and children, as explained below. 
political conflicts caused by the present day transition process, without reference to these historical roots. Neither the invasion of Christian independent churches nor the migrant labour system, for example, which have been considered a major base of resistance, violence and witchcraft accusations in Tsolo and Qumbu, were just reshaped by the colonial powers according to their own needs or to the demands of the world market, as some liberal or Marxist scholars maintained in the past. They developed in reaction to complex, sometimes antagonistic structures of global and local politics and belief systems, closely related to these colonial demands (cf. Bernard 1995: 176).

In the early 1990s, with the beginning of the final phase of the transition from apartheid, a new cycle of violence started in the districts of Tsolo and Qumbu which grew to dimensions never seen before. Police statistics accounted for 1,021 murders and 424 cases of attempted murder, just for the period 1994-1997 (Minnaar 1998: 1). ${ }^{22}$ Stock theft and witchcraft accusations were regarded by the stakeholders and the local press as central motive of the violence in Tsolo and Qumbu during the $1990 \mathrm{~s}^{23}$ But this seemingly obvious local conviction was by no means unambiguous. It had to be interpreted against the historical background of the conflict. Stock theft was nothing new, either in rural areas of Eastern Cape or in South Africa in general. In the Transkei, however, it differed significantly for example from the Northern Cape, where principally commercial white farmers were targeted. In Tsolo and Qumbu, stock theft was mostly about 'the poor stealing from the poor', as a police report put it in $1997 .{ }^{24}$ This seems to be a peculiar interpretation, possibly derived from apartheid rule, when African farmers were generally

22. According to Minnaar (1998: 1), there are no collated police statistics available prior to 1994. As in the Northern Province, the actual number of victims was probably considerably higher, because many victims and their relatives were afraid to report the attacks to the police, for fear of reprisal.

23. 'National probe of Transkei killings urged', by Bronwen Roberts and Simphiewe Xako, Daily Dispatch 28.11.1997; and 'Women caught up in cycle of violence', Daily Dispatch 28.11.97. The following chapter relies heavily on HRC reports (1996; 1997), Minnaar (1998), and Peires (1994; 1999), as well as on newspaper reports of the Daily Dispatch. The close relationship between thieves and witches has also been observed in other African societies, like the Gisu of Uganda (see Heald 1999: 73-89). However, in these cases, both thieves and witches had been associated mostly with the deviant behaviour of deprived people who lack sufficient resources for survival, notably young and old women (ibid. 87).

${ }^{24}$. Louw \& Shaw 1997: 127-9). According to a recent survey on stock theft in Eastern Cape by Prof. Geoff Antrobus, Dept. of Economics, Rhodes University, stock theft in Eastern Cape accounted for more than a quarter of all stock theft cases in South Africa. The poorest farmers in the former homelands were the worst hit, bearing up to $90 \%$ of the losses. Many stock theft cases were linked to commercial theft, not for potslag (killing for the pot); thus in Tsolo armed men recently opened a whole kraal of livestock and drove them off, firing shots at the homestead (Daily Dispatch 17.10.2002). 
considered an amorphous mass of poor peasants. Between the lines it probably meant, 'Africans stealing from Africans', thus hinting at an internal ethnocultural conflict. However, socioeconomic differentiation within Tsolo and Qumbu districts was considerable. According to Peires (1994), the long-standing tradition of organised cattle theft in Qumbu, as well as the communal social resistance organised against it, recalled Anton Blok's (1975) famous interpretation of the history of the Sicilian mafia. The thieves were unsocial bandits who constituted themselves into a kind of local aristocracy which, in alliance with official right-wing elements in the local administrative structure, terrorised those from whose very ranks they had managed to rise. ${ }^{25}$

Another major trait of the conflict had to do with legitimacy and was connected to the long history of resistance and revolt in this part of the country. The apartheid state in general and its policing structures in the Transkei, in particular, were not considered as legitimate by the local population. They were built on colonial forms of control and had been designed to guarantee the state monopoly of violence, often in close collaboration with traditional chiefs, rather than to deliver services. ${ }^{26}$ No wonder that people of Tsolo and Qumbu in the 1990s did not trust the state, the police or the courts. Time and again the legitimate representatives of the villagers had applied for better protection, requested police raids for the confiscation of illegal firearms, and reported murders to the police, but next to nothing had been done. ${ }^{27}$

\footnotetext{
${ }^{25}$. See Peires 1994: 2-3; 2000: 98; Blok 1975. According to Crais (2002: 168), many stock thieves were among the most wealthy people in the region, who, according to the chief magistrate in 1957, 'constituted themselves into a sort of aristocracy which did not mix with lesser folk'. The HRC report (1997) also stated that stock thieves were apparently well organised by members with resources, and allegedly assisted by gunrunners, local farmers, the police and butchers who bought meat cheaply from the thieves.

26. See Louw \& Shaw 1997: 133-40): 'Colonial forms of control policing were interwoven with other forms of local authority, district commissioners, magistrates, chiefs and headmen, to ensure compliance among the poor.' At least up to the 1980s the headman's role of policeman and informer of local magistrates persisted. The collection of intelligence, control and safeguard of order remained the key role assigned to state agents like the local police: 'in short, the poor were not policed, they were spied on. A visible policing presence was often more a cause for concern than a source of security.' For a more detailed analysis, see Peires 1992, 2000.

27. In 1996 the Institute of Security Studies (ISS), Johannesburg, started an Arms Management Programme intended to stop the illicit trade in arms. This programme was extended to Tsolo and Qumbu, without evident success (see 'Strife-torn communities favour gun control', Business Day 14.02.2002). Once Bebeza, an honest traditional leader in Tsolo, had been murdered by thieves in February 1998, increasing the number of traditional leaders killed in the region to at least three, and the State Security units refused to protect the chiefs as in the past, they reverted to silence vis-à-vis official structures (Peires 2000: 103).
} 
In fact, traditional leaders had already looked for informal structures of self-defence and developed a self-help attitude to justice. In view of growing insecurity, traditional policing by vigilante groups, closely related to the traditional occult belief system and its secret cults of policing, were revitalised and complemented by modern features, a phenomenon well known from mushrooming vigilante groups in other parts of South Africa (cf. Baker 2001; Schärf 2001) and sub-Saharan Africa in general, as in Benin, Ghana, Nigeria and Tanzania. Thus a native vigilante organisation called Mfelandawonye was founded in 1993 to counteract the antisocial bandits. ${ }^{28}$ This organisation apparently saw itself as maintaining the tradition of resistance of the Mpondo in general, and the Makhuluspan revolt mentioned above in particular. ${ }^{29}$ This legitimate resistance to oppression by the stock thefts was apparently interpreted by the thieves and their followers as a declaration of war. They formed their own secret society, known as the Amampondomise Thieves Unit or Inkqayi (HRC 1997: 5). ${ }^{30}$

The major objective of the Mfelandawonye vigilante group was, according to its own declaration: 'Thieves, witches, and informers must be exterminated to the last man or woman' (cf. Peires 1999: 12). This declaration about its target groups is decisive, as it helps to illuminate the linkage between the different facets of violence. Though at least three distinct groups of evil were identified, they were closely interwoven. In practice, it was hardly possible in many cases to separate witchcraft accusations from other

28. Umfelandawonye, or Mfelandawonye, literally 'those who die in the same place', or in short 'we die together' had its roots in a traditional burial society. The similarity, at least in name, to the Amafelandawonye resistance movement of Hubli women in Herschel in the 1920s mentioned above, was striking and probably intended. According to Peires (1999: 7), the name, deliberately archaic in tone, had been part of the traditional political vocabulary of the Transkei. By referring to these historical roots the vigilante group possibly sought to legitimate its activities. The Mfelandawonye may be compared with the Mapogo $A$ Mat(h)amaga, the largest formal South African vigilante organisation, founded 1996 in Northern and Mpumalanga provinces with some 50,000 members, according to its own claims. However, for reasons still to be investigated, the Mapogo apparently hardly became involved in witchcraft violence, although their members applied their own brand of African medicine to the suspects as well (see Baker 2001: 4).

29. See Crais 2002: 165-77 and Peires 1999: 7-12 for more details of the 'anti-theft movement' responsible for the Makhuluspan disturbances (1957-61), usually referred to in Tsolo as Tutselane (from the name of the first thief to be killed).

30. 'Others in the community maintain that the unit was created when Umfelandawonye accused some men of being thieves after the men refused to join the organisation. Because they were labelled as thieves and subsequently intimidated and threatened, the men were forced to resign from their jobs and return to the Transkei. According to this interpretation, after returning home, they came together and formed the Amampondomise Thieves Unit and decided to steal from members of Umfelandawonye working in the mining industry.' (HRC 1997: 5). 
accusations, as for example, the Truth and Reconciliation Commission (TRC) hearings on politically motivated violence in other parts of the Transkei demonstrated. Even if killings had been clearly motivated by other reasons, this did not explain sufficiently in the emic view why the culprits did not select another prey. Therefore, quite often close kin was accused of collaborating by means of witchcraft. ${ }^{31}$ This may hold generally for small-scale societies, dominated by personal relationships and a worldview in which nature and social relations are so simplified that accident as an explanation for personal misfortune hardly exists, but is usually replaced by suspicion of witchcraft, as Monica Hunter-Wilson (1951/1970: 260-1) and others (cf. Kohnert 1983) maintain. Yet it seems to be especially true for the Pondo, where the external influence of pluri-local social networks accentuated longstanding cleavages between clans, castes and social classes, already analysed by Hunter-Wilson (1970: 258-61) some 50 years ago. All this probably also contributed to a growing incidence of witchcraft accusations, but - contrary to witchcraft accusations in Venda - not directly and overtly (cf. pp. 5ff), but indirectly, induced by external forces, and camouflaged by growing mistrust against the unknown enemy within its own group which supposedly collaborated with these external enemies. Actually, in its helpless and increasingly dogmatic efforts to counteract the violence of the thieves organisation that was closely related to the more affluent and powerful conservative members of the society, Mfelandawonye attacked not only known or suspected thieves, but assumed witches, old people and children, 'in fact anybody who did not wish to associate with it' (cf. Peires 2000: 98), thus putting anybody who did not act for it on equal footing with its enemies.

The report of the independent non-governmental Human Rights Committee (HRC) hinted at yet another important reason for the creation of the Mfelandawonye. It was linked to the realm of religious and occult belief, i.e. the protection of the very socio-cultural and religious base of Mpondo society, important for maintaining protection and peace within the community, and to its roots as a traditional burial society: 'The community was

\footnotetext{
31. See TRC, Human Rights Violations, submissions, Questions and answers, 18/20.06.1996; 24.09.1996 <http.//www.doj.gov.za/trc/hrvtrans/ ...Umtata/lupond.htm, .../Duncan/kumalo.htm>. The TRC was officially established in 1995, in the aftermath of the first independent non-race elections, under the chairmanship of Archbishop Desmond Tutu to deal with the crimes of the apartheid regime. Overloaded with high expectations of a uniquely African way of conflict resolution, the history of the TRC revealed that opportunities to build a 'reconciliatory bridge' promoting development were limited. For more detailed accounts see Campbell 2000; Maluleke 2001; Stanley 2001.
} 
concerned not only with the violence but with the negative impact stock-theft was having on their culture. Cultural practices, such as slaughtering cattle during funerals and sacrificing goats during the graduation ceremonies for traditional healers, needed to be protected. Saving these cultural practices was one of the initial goals of the organization' (HRC 1997: 5).

Last not least, a dominant trait right from the beginning of the new wave of violence in 1990 was ostensibly linked to gender problems, notably the jealousy of migrant workers vis-à-vis their wives. Investigation of the Mfelandawonye in general, and of the witchcraft aspect in particular, became increasingly difficult because of its extremely close-knit gender specific grouping. Strong clan and family ties, already identified by Hunter-Wilson (1970: 258-60) as a major source of witchcraft accusations, ${ }^{32}$ also characterised the Mfelandawonye. In fact, the emphasis on gender separation in the social structure of the Mpondo in general, and the division between the sexes in witchcraft accusations, in particular, had already been underlined by Heinz Kuckertz (1990: 290) and Hunter-Wilson (1951/1970: 260) respectively. ${ }^{33}$ The familiar as a symbol of forbidden sex attraction, and sex antagonism, in general, are both well known as major sources of witchcraft accusations all over Africa (cf. Kohnert 1983). However, this explanation remains isolated and static, even if related to a peculiar social structure or the specific cultural heritage of the Mpondo. The rigid gender-specific dividing lines alone cannot explain the modernity of present-day witchcraft accusations among the Mpondo. These have to be linked to the production

\footnotetext{
32. Among the Pondo, 'the men of a homestead form a close-knit group, ... being jointly responsible for each other's torts and fighting as a unit in the army of the district. A number of lineages make up a clan, which though not strictly a territorial group, has a territorial headquarters ... only kinsmen live together, and kinsmen can expect to benefit from the herd of their wealthy relatives either through inheritance or by assistance with marriage cattle, so every man has a personal interest in the increase of cattle belonging to the kinsmen with whom he lives.' (Hunter-Wilson 1951/1970: 258-60).

33. Kuckertz (1990: 290), in his painstaking anthropological study of the homestead as a cradle of Mpondo social life, emphasises that although Mpondo women are extremely dependent on men, notably in the legal domain, both men and women must strictly observe the customary dividing line between the sexes. Transgression of this boundary creates suspicion of evil intentions and witchcraft. Hunter-Wilson (1951/1970: 256) also related witchcraft accusations to the specific social structure of the Pondo, notably 'the system of clan exogamy, which excludes large categories of individuals living in the same neighbourhood from marrying or flirting with one another'. As the Pondo bride joins the homestead of her husband and lives under the control of her mother-in-law, conflicts between them resulting in witchcraft accusations are quite common; the same goes for quarrels between fellow-employees in the mines or elsewhere.
} 
process, its historical development, and the increasing involvement of the stakeholders into trans-local social networks outlined above.

Because of deteriorating economic conditions in Tsolo and Qumbu, further accentuated, in the view of the concerned, by the increasing discrepancy between the growing deprivation of the area, and disappointed high local expectations connected with the end of apartheid, most men from Qumbu and Tsolo, especially the younger ones, decided to look for work in the mines outside the Transkei (mainly in the Vaal Triangle in Gauteng). They had to leave their families and wives behind, which created fears and allegations among many migrants that during their absence their women might enter into dishonest relationships with other men.

'Once a woman is accused of adultery, she is targeted and attacked. ... According to one of the victims, killers have been heard to say that they will kill 'Oqhira' - perceived witches and 'Izifebe' - perceived prostitutes. According to the Red Cross, armed men go into Sulenkama in Qumbu when husbands are away and offer to protect the women and children. Often women are forced to harbour these armed men who are alleged stock-thieves. ... The women ... maintain they only harbour the men because they want protection. Furthermore, refusal to accommodate these armed groups could result in the entire family being accused of membership of Umfelandawonye (anti-stock theft group) and consequently in them being attacked. It is evident that women are caught in a catch 22 situation, with no way out of the cycle of violence.' (HRC 1997:10)

According to official sources, there was a steady increase in violence against women and children in Tsolo and Qumbu districts from 28\% in 1995 to 35\% in 1996 and $43 \%$ in the first eight months of $1997 .{ }^{34}$ Closely related to the special 'sex-antagonism' mentioned above, there was another modern link between witchcraft accusations and gender, which research prior to the 1970 s could hardly conceive: the growing menace of the AIDS pandemic. This was especially virulent among the poor of this area, and elderly women especially were accused of having bewitched the AIDS victims. ${ }^{35}$

\footnotetext{
34. See HRC 1997: 3, and 'Women caught up in cycle of violence', Daily Dispatch 28.11.97; S. Xako: 'Human rights body notes 12 death in Tsolo, Qumbu', ibid. 28.01.1998.

35. As East Griqualand-Kei regional health director, Chake Ngoma, explained: 'Many innocent people, mostly elderly women in rural areas, have become victims of witchcraft murders. ... More often than not, these people are beaten or burnt to death on the basis of false stories implicating them in Aids-related deaths in their neighbourhood.' See P. Ngani: 'Father goes public on son's Aids death', Daily Dispatch 18.12.1999. Ngoma backed government-sponsored awareness campaigns in Flagstaff and other parts of Eastern Pondoland, a region adjacent to KwaZulu-Natal, regarded in health circles as South Africa's 'Aids capital'. In
} 
Shortly after the publication of the 1997 HCR report and subsequent awareness campaigns, twelve more people were killed in the strife-torn Tsolo area in the month of January 1998 alone. In October of the same year three elderly women, accused of practising witchcraft, were murdered in their homes at Nmadolo near Tsolo (Daily Dispatch 5.10.1998). At the end of the month further three women were burned to death after they were abducted from their home at Dengwane village, Mount Fletcher, by unknown killers (ibid. 30.10.1998). In November 1998 police headquarters in Umtata reported more than 100 attacks, predominantly due to witchcraft accusations, carried out by gunmen on defenceless women and children in Tsolo since the beginning of the year. ${ }^{36}$ In a bloody New Year's eve massacre of 1999 eight people, five mostly elderly women and three men were murdered in Tsolo, while at least 13 others were killed in neighbouring areas. According to police investigations, the culprits were assassins hired to eliminate people, mainly women, associated with witchcraft, as Superintendent Nondumiso Jafta of Umtata headquarters explained. ${ }^{37}$

According to the HRC (1997: 4), the nature of violence in Tsolo and Qumbu changed after 1995. First, the number of reported stock-theft cases decreased, and second, other towns in the vicinity such as MacLear and Matatiele also had problems with stock-theft and witchcraft, which however did not result in a similar cycle of violence. Apparently, there were still other aspects of the actual conflicts in Qumbu to be considered (cf. Peires 1994; 1999). 'For example, people have used stock theft to settle old grudges by labelling their opponents either "umfela" or "thieves"; others have found a market for gunrunning, and political parties have claimed that a turf war is being fought to destabilize the area., ${ }^{38}$ The deliberate political destabilisation of the area by 'third forces', had already been alleged with substantial evidence by ANC and South African Communist Party (SACP) sources. But high-ranking local ANC representatives themselves became deeply involved

addition the myth, circulating within the realm of the occult belief system, that men infected with the HIV virus could cure themselves by sleeping with a virgin, contributed to the growing curse of child and even baby rapes, especially among the poor in Venda and Eastern Cape; see 'Government faces growing epidemic of child rapes', South African Press Association, Johannesburg, 07.11.2001. See Ashforth 2001: 179 for the challenges to democratic government and legitimacy of the state posed by the linkage between AIDS and witchcraft.

36. See S. Xako, 'Killings blamed on witchcraft', Daily Dispatch 11.11.1998.

37. P. Ngani, '21 die in bloody T'kei weekend', Daily Dispatch 04.01.1999.

${ }^{38}$. See here and in the following: SAPA PR Wire service: 'Tsolo-Gauteng violence links', 27.11.1997. 
in the vicious circle of killings and counter attacks (cf. Peires 1999: 5-6, 10-1). ${ }^{39}$ In June 1998 the TRC opened an inquiry into the controversial role of former apartheid security personnel in the Transkei killing fields of Tsolo and Qumbu. Among others, the feared Superintendent Frans 'Lappies' Labuschagne, later a top Mpumalanga detective with a shadowy past, as revealed by convicted Vlakplaas killer Eugene de Kock, applied for amnesty for his involvement in gun smuggling from Mozambique, used to provide hit squads in the 'internecine violence in Tsolo and Qumbu', as well as for his connections to police spy accuser Vusi Mbatha, and his role in the conflict. ${ }^{40}$

Originally founded with the explicit aim of a legitimate defence against the enemies of Pondo society, the Mfelandawonye, later on, turned to the violent resolution of any serious dispute, about land, inheritance, family feuds, which might previously have been solved peacefully. Now it initiated a circle of revenge attacks and witchcraft accusations (cf. Peires 2000: 99), concerning any inter-personal, social or political conflicts which could be associated with witchcraft.

On 3 February 1995, President Nelson Mandela, himself born in the Transkei, visited Tsolo in person. He warned at a public rally that unless the "politically-motivated stock theft' did not end, he would be compelled to send in the army (cf. Minnaar 1998: 5). Even this engagement of the most highly respected political leader and national hero apparently did not curb the violence. A special police task force of 35 men was put together in Tsolo to stop the violence, but as it became evident that many of the 'hitmen' were migrant labourers based in the Gauteng mines, additional smaller police teams were formed in

\footnotetext{
39. The Transkei had been regarded as stronghold of the ANC and the 'communist terrorists' by the security breaches of the apartheid police, notably since the 1980s; see Umtata-Amnesty-Hearings of the TRC, 27.03.2000, of the Captain in the South African Police Force and Acting Station Commissioner for the district of Qumbu, Mr. Siqhola, who, according to his own confessions, participated in the torture of ANC members <http://www.doj.gov.za/trc/amntrans/2000/00032728UMT/200327um.htm>.

40. According to preliminary TRC investigations, indirectly confirmed by Eastern Cape MEC for Safety and Security Dennis Neer, links had long been suspected between Mozambique gun-running, pre-election activities by the infamous Vlakplaas security police hit squad run by De Kock, the mines, and stakeholders in Tsolo and Qumbu. From 1994 there were persistent rumours that the thieves and their followers had been trained and supplied by militants of the ultra-right Afrikaner Weerstandsbeweging (AWB) in neighbouring Maclear (see Peires 1994: 22) and Port St. Johns, in order to stop the 'communist' vigilante groups of the anti-thieves, supposedly backed by the ANC and the SACP; see P. Dickson, "'Lappies" linked to gunrunning', Mail \& Guardian 04.12.1998.
} 
Secunda and Vanderbijlpark to assist the Transkei police. ${ }^{41}$ Over the next six years or so, the situation, fuelled by increasing involvement of trans-local social and political networks with particular interests on both sides, got out of control and degenerated into a circle of increasing terror and violence. While local residents were killed indiscriminately, other inhabitants including children fled their homes in fear of further attacks. Property and homes were destroyed. Tsolo migrant workers from Gauteng came to play a major role in the movement, which had its head offices in Vereeniging in Gauteng, some $30 \mathrm{~km}$ south of Johannesburg. The Mfelandawonye, now composed of local people as well as migrant workers stationed in Gauteng, allegedly coordinated the violent attacks by drafting hit lists and even using young unemployed youth between the age of 16 and 20 years to execute their demands (HRC 1996: 11). ${ }^{42}$

In this phase of the transition process, not only inter- and intra-group political party feuds, but also conflicts between the new Local Government structures, the Transitional Rural Councils, traditional leaders and the Transkei branches of the South African National Civics Organisation (SANCO), and last not least illegal trade of criminal syndicates dealing in firearms and drugs, notably dagga (marijuana) from the Transkei into the whole of South Africa, added to the violence (cf. Minnaar 1998: 2-7 for more details). Deteriorating socio-economic conditions in the region further fuelled the violence. ${ }^{43}$ Young migrants from Tsolo and Qumbu were looking for employment in the industrial centres of Vereeniging or the mines of Secunda, Rustenburg, Welkom and the East Rand; but the profit expected from gunrunning, murder and intimidation seemed to be even more promising to some of them. ${ }^{44}$ Gunrunning from Gauteng and KwaZulu Natal to Tsolo,

${ }^{41}$. See 'National probe of Transkei killings urged', by B. Roberts \& S. Xako, Daily Dispatch 28.11.97; and SAPA PR Wire service: 'Tsolo-Gauteng violence links', 27.11.1997.

${ }^{42}$. One especially crude example illustrates the ambiguous nature of politically motivated violence linked with occult belief in the Transkei: in July 1997, four men armed with R4 and R5 rifles and a shotgun burst through the door of a hut and opened fire on a birthday party in Qumbu. Four children and two women accused of witchcraft were slaughtered. East Cape Safety and Security MEC, Dennis Neer, asserted that the murders were political, and not related to stock theft: 'We cannot wait for the killings to continue before we are convinced that there is a well-orchestrated and systematic plan to destabilize so-called flashpoint areas in the former Transkei.' See 'Third force agents are killing our children', SAPA PR Wire Service, Bisho; East Cape News 18.07.1997.

43 . See B. Roberts, 'Millions to be spent on strife-torn Transkei Towns', East Cape News 14.07.1997.

44. 'Even labour centres, such as the Employment Bureau of Africa (TEBA), were alleged to be recruitment centres for the killers and distribution centres for the weapons they used.... The ANC has noted with concern that unemployed men could easily fall prey to the warlords running the area. Young people, 
where there was a good market for weapons, was apparently lucrative. These growing markets of violence have been considered a further major underlying factor of the conflict, in which highly sophisticated weapons, such as R1, R4, R5 and AK-47 automatic rifles were frequently used (cf. HRC 1997: 7; Daily Dispatch 28.01.1998). It may be taken as another sign of the occult economy reigning in this area, that this modern equipment by no means prevented the young hit men from asking traditional healers for magical protection for their murderous deeds. One of the suspects arrested for murder in Tsolo confessed that 'intelezi' was commonly used as muti (traditional medicine) before going to attack (HRC 1997: 8). Concerning the instigators of the violence, the HRC (1997: 9) remarked: 'Tsolo and Qumbu are believed to be monitored by coordinators, networked in the area, who compile lists of those perceived to be either thieves or witches. These people are to be killed ... Another list of people to be killed is alleged to have been compiled by people in Gauteng.'

In 1998 the tentacles of the Mfelandawonye spread to Cape Town. It killed at least 14 Cape Town residents between May and August 1998, 10 of them in Khayelitsha in just one week, all of them from Qumbu. ${ }^{45}$ The public order police superintendent in Tsolo-Qumbu, Wayne Hackett, described the organisation as a 'third world mafia', charging membership fees and extorting money to protect herds, acting according to the maxim 'if you don't join, you are eliminated'. He saw the migrant labour system as a key problem and said it was only logical that violence in the rural communities would follow the workers to the cities. $^{46}$

hoping to find employment in the local industries, are especially susceptible to the influence of these warlords. They have come to the area seeking employment in the local industry. On arrival in Vereeniging, some are trained not to work in the mining industry, but to work as hit men' (HRC 1997: 6/7).

45 See Myolisi Gophe \& Patrick Burnett, 'Kei mafia swoop on city', Cape Argus 14.08.1998; Grawitzky Renee, 'NUM leader Mphenis murder blamed on inter-union rivalry', Business Day 15.10.1998

46. In another report, rivalry between factions of the National Union of Mineworkers (NUM) and the Mouth Peace Workers' Union were linked to the murder of 14 miners on the Lonroh Platinum mines in 1998 and to continuing violence in the Tsolo-Qumbu area, which had spilled over into the mines; see Renee Grawitzky, 'NUM leader Mpenis Murder Blamed on Inter-Union Rivalry', Business Day 15.10.1998. 


\section{The impact of Trans-national Social Spaces on reconciliation and development} Reconciliation backed by sympathetic TSS-networks in Limpopo Province

Certainly, in the emic view, a major driving force behind the witch purging movement in Venda and other parts of Limpopo Province described earlier had been good intentions on the side of the perpetrators, and the villagers' legitimate concern to rid their community of the evil. But without question, it was misguided from the beginning. The sudden outbreak of witchcraft violence aroused considerable interest far beyond its regional setting. Not only were state security organs alerted, but also political parties, civic organisations (including that of traditional healers and chiefs), and scholarly research at national and international level. This surprising wave of public concern with the violence had certainly to do with its peculiar nature, i.e. its apparent linkage to occult belief systems, deeply rooted in the African past, and the current political discourse on African Renaissance and empowerment in South Africa. The 1998 National Conference on Witchcraft Violence in Northern Province, organised by the Commission of Gender Equality (cf. CGE 1998), and the broad coverage of results of discussions and follow-up workshops in the media, made it clear that representatives of every relevant social and political group in South Africa wanted witchcraft violence to be stopped as soon as possible. However, the painstaking and detailed problem analysis by the stakeholders, published in the annexe of the CGE report, revealed considerable differences in the evaluation of the underlying factors. There were strong voices among representatives of political parties and civic organisations, also reflected by the report of the official Ralushai Commission (1995: 48, 64), maintaining that African occult belief systems, including the belief in witchcraft, had to be considered as an integral part of African culture, which could and should not be uprooted. Although sharply contested, this post-apartheid vision on the reality of witchcraft represented an important shift in the official and public discourse about witchcraft (cf. Niehaus 2002:184-85, 199). The massive and hitherto unimaginable involvement of the state, trans-local and even trans-national social, political and academic networks in a local discourse on witchcraft, driven by an understanding attitude vis-à-vis the stakeholders concerned (unlike early colonial administration and missionaries, cf. Redding 1996a: 257), and the weakness of 
counteracting vested interests of other implicated groups, opened new chances for conflict resolution.

Reconciliation in Limpopo Province proved to be difficult, but not impossible. Next to the impact of trans-local forces on conflict resolution just noted, it was probably facilitated by the relative strong inward orientation of the population already described: i.e. the low profile, if not absence, of trans-local social networks which sought to profit from the violence, the strong backing for witch-hunts by the villagers, and the corresponding legitimacy of the persecutors in the emic view. In May 2000 the TRC began its hearings on witchcraft violence in Northern Province. ANC supporters, convicted in 1990 and serving long-term sentences for their attacks, applied for amnesty for the murder of 26 villagers in the former Bantustan of Venda between 1989 and 1993. The applicants claimed they perceived their victims as persons who were practising witchcraft and in doing so, were collaborating with traditional chiefs and politicians of the hated 'homeland' government of Venda. The TRC finally granted amnesty to 33 applicants in June 2000, with ten others refused amnesty. TRC investigations also found strong evidence to back the assertion that the chiefs of the districts, who formed a tier of government at that time, were also associated with 'ritual murders' connected to witchcraft accusations, in order to maintain their political power. ${ }^{47}$

The government believed that the TRC had assisted the healing process considerably. Recent academic evaluations of the exercise are less optimistic (cf. Maluleke 2001; Stanley 2001). Notwithstanding confident public declarations, witchcraft murders did not stop once and for all, although the reported incidence diminished after $1997 .{ }^{48}$ Whether this decline at least in the most harmful impact of occult belief was sustainable remains to be seen.

\footnotetext{
47. The final committee of the TRC, which had to consider amnesty applications, was dissolved in May 2001. It wanted to consider its findings before producing a final report by the end of the year 2001, but in April 2002 the report had still not been published. For further details and names of the stakeholders involved see TRC 2000, 'Granting and denying of amnesty to witchcraft killers', Statement by the Amnesty Committee of the Truth and Reconciliation Commission, 14/06/2000 <http://.www.gov.za/...>; and 'Truth Commission hears witchcraft amnesty applications', PANA, 08.05.2000. For more detailed accounts of different TRC-witchcraft hearings see ANC-news, 'Truth-Rakgotho: Woman killed for sprinkling water on the road: TRC', Johannesburg 28.02.2000; and ANC-news, 'Truth-Witches, eight more seek amnesty for witch killings in NPROV', Thohoyandou 09.05.2000.

${ }_{48}$ According to police reports, more than 500 people accused of being witches were murdered between 1997 and 1999. Provincial police researcher Captain Prince Makgoshing reported decreasing figures of death related to witchcraft violence, but the number of (illegal) witch-hunts was on the increase for reasons which
} 


\section{Reconciliation hampered by hostile TSS-networks in the Transkei}

The different nature of trans-local networks and modes of production fuelling the hotbed of violence in the Transkei analysed above, put local reconciliation efforts at risk right from the beginning. Witchcraft related violence, although hidden, was considerable here as in Limpopo Province. But it did not draw the sympathetic attention of external actors as in Limpopo Province, for the reasons already explained. The 'case' of Tsolo and Qumbu was therefore handled by the post-apartheid authorities by the conventional means which most democratic government use for outbreaks of domestic violence in disfavoured regions: policing, awareness campaigns and development programmes, as usual, hampered by the constraints of inadequate resources and ineffective projects. Yet it would be misleading to excuse the lack of interest in the violence, notably in its occult dimension, merely as ignorance. Because of its sensitive political nature, the conflict was covered by a longstanding 'culture of silence and untruth' (Peires 1999: 1-2), comparable only to the apparently politically motivated disguise of the aftermath of the conflicts in KwaZulu Natal in the 1990s by the post-apartheid regime. Apparently, the inquiries of the Kroon Commission, the HRC, and the TRC in 1998 on the violence in Tsolo and Qumbu referred to above, were not followed up with the necessary vigour and backing.

As the hostilities had not been reduced by high visibility police and army patrols, and because secret undercover police investigations in the Tsolo-Qumbu area had brought no arrests either, the Eastern Cape Minister for Safety and Security, who claimed the government knew who the ringleaders were in the chaos, promised drastic steps. ${ }^{49}$ In September 1997, his department submitted proposals for new policing strategies and measures, especially in Qumbu and Tsolo areas in the light of violence, continuing in spite of the deployment of the SA National Defence Force in the area.

still have to be investigated. According to the latest available figures, there were 73 reported cases of witchcraft violence in the first six months of 2000 in Northern Province. See 'Truth Commission plans public hearings into witchcraft', African Eye News Service (South Africa), 24.02.2000; and 'Address by Northern Province MEC for safety and security and liaison, Mr. Ek Nong, at the launch of the campaign against witchcraft violence and rape', Bushbuckridge, 18.07.2000.

49. See East Cape News 18.07.1997: 'Third force agents are killing our children'. 
Because overall poverty was regarded by the regional government as a major underlying factor of the violence, a Presidential Project Team (PPT) plan to overhaul and develop the towns had already been recommended in 1996. PPT spokesman Matthew Moonieya announced in July 1997 that Tsolo and Qumbu were among eight towns that the PPT wanted to develop. Although the towns had been chosen because they fell within the scope of the Wild Coast Spatial Development Initiative, and not necessarily because of their dismal political situation, the authorities believed that development would reduce the level of violence. ${ }^{50}$ Whether these activities delivered the expected results is open to question. Three years later similar headlines appeared in the press: 'Tsolo and Qumbu killing fields ploughed over by development, says Govt', ${ }^{51}$ was one of them, reporting a significant decline in violence as result of different development projects, as indicated by 39 murders between January and March 1996, compared with just over 10 in the same period of 2000 .

State institutions, notably the police, reinforced by the army, tried to curb the violence further. In September 1998 the head of a special investigation task force of the police claimed that the killings in Tsolo-Qumbu area had dropped by about $50 \%$ in the past year. It was hoped that the presence of soldiers, who had set up a military camp in the region, would (like the intervention of Cape Mounted Riflemen some 90 years before) bring stability to the conflict-torn communities, although police admitted lasting insecurity, especially after sunset. ${ }^{52}$ However, as the country was approaching the 1999 general elections and the subsequent Local Government elections of 2000, the political atmosphere remained tense. It was thus by no means certain that police and army pacification actions,

\footnotetext{
${ }^{50}$ Moonieya announced that about R2 million would be spent on each town to start the development scheme, called 'Integrated Development Plan and Programme'. Once agreement had been reached, the PPT wanted to conduct situational assessments in the towns and discuss priorities with residents. The other towns were Flagstaff, Lusikisiki, Bizana, Engcobo, Idutywa and Mount Frere. The PPT, set up in 1996 to build the crumbling Transkei towns, had already embarked on similar development programmes in Umtata, Butterworth, Mount Ayliff, Port St Johns and Cala. The Kei and Wild Coast district councils had also been set up and were supplying expertise to local governments. See B. Roberts: 'Millions to be spent on strife-torn Transkei Towns', East Cape News 14.07.1997.

${ }^{51}$. P. Burnett, 'Tsolo and Qumbu Killing Fields Ploughed over by Development, says Govt.', East Cape News 23.03.2000

52. See M. Zifo: 'Qumbu, Tsolo killings down 50 pc - police chief', Daily Dispatch 04.09.1998.
} 
combined with development projects, education and awareness campaigns of state and civic organisations, would bring about the much-needed reconciliation in the area ${ }^{53}$

The local population was not convinced by the government's optimistic outlook. Neglected by the outside world, it decided once again to take peace and reconciliation into its own hands. Trusting in its own local culture that considered public confession of the truth behind the aggression as the ultimate condition for any conflict resolution, it applied principles similar to the TRC at the national level, but unfortunately with different results. At the end of May 1999, the Mfelandawonye invited the local population, state representatives and the police for 'peace talks' in Jence, some 20 kilometres from Tsolo. ${ }^{54}$ Since 1993 more casualties had been observed there than in any other area of the Tsolo and Qumbu districts. The wave of killings which led the Mfelandawonye to request a special peace meeting was triggered by the Majaba Massacre on New Year's Day 1999. After Christmas 1998 one member of the Mfelandawonye had been killed in Jence by lightning, a clear sign of witchcraft in the emic view. In a revenge operation, members of the society burst into the funeral gathering, killing the presumed witches, the deceased's mother and female relatives, a total of eight people (cf. Peires 1999: 15).

More than 300 residents followed the invitation to an indaba on 15 May 1999. The atmosphere of the meeting was tense since many villagers considered Mfelandawonye,

53. In January 1999, an interim coordinating committee (ICC), regulating traditional medicine throughout the country, reconfirmed its stand against witchcraft-related violence in Eastern Cape Province. In a statement after new witchcraft-related murders of eight people at Tsolo, the general secretary of the ICC, Lizwi Nduku, boasted of its commitment to resolve witchcraft-related violence as one of its major achievements in honouring recommendations by the National Conference on Witchcraft Violence in 1998 and the subsequent Thohoyandou Declaration (see Daily Dispatch 06.01.1999). The provincial spokesman of United Democratic Movement (UDM) in East London, Mabandla Gogo, demanded on 15.011999 that Tsolo district should be declared an 'emergency area' because of the virulence of violent conflicts. He called on the Amampondomise to forget about political affiliations and to hold an Indaba, a local truth and reconciliation meeting, to establish the facts and identify locally adapted solutions which could be recommended to the national government, as 'Bisho [the provincial capital] does not have the stamina to carry out the task.' Notably because of approaching elections, Tsolo and Qumbu areas needed to be strongly monitored according to the UDM, as they could be used by enemies of democracy. The party challenged the provincial government for not publishing the findings and recommendations of the Kroon Commission and condemned the lack of visible and reassuring police presence in the area. See Z. Mpondwana: 'UDM: Emergency in Tsolo', Daily Dispatch 16.01.1999.

54. See here and in the following Peires 1999: 14-21, who attended the meetings personally, and S. Mzimba: 'Community stands together against "We die together", Daily Dispatch 25.05.99, for a more detailed account. Jence had already gained a notorious reputation as one of the hot spots of violence during the Makhuluspan revolt and had been selected by the apartheid security forces as one of its 'workouts' in 1961. 
which had degenerated into a nationwide network, alienated from local concerns, to be the chief culprit of extra-legal killings. However, Livingstone Mntonga, the general secretary of the organisation, present at the meeting, rejected this allegation and blamed 'witchdoctors' of the area as the real culprits of the killings. ${ }^{55}$ One week later residents belonging to Mfelandawonye agreed that those of their members, whom they believed to be involved in witchcraft, should be arrested in connection with the Majaba killings. According to police sources, both sides agreed to stop the killings. ${ }^{56}$ A follow-up peace and reconciliation meeting at Jence on 29 May 1999 appeared at first sight as a partial success. However, no Mfelandawonye members from outside the village were allowed to attend. This attempt of the village community to restrict the conflict and its aftermath to the local level was comprehensible. But it killed any sustainable conflict resolution in the bud, because of its disregard of its essential trans-local dimensions. Although the local members, after some hesitation, confessed the truth about former killings, they could hardly appease the community for their personal misdeeds, let alone those of the Mfelandawonye in general (cf. Peires 1999: 18-21).

Thus, a unique chance of a self-reliant local peace and reconciliation process, meant to reverse the vicious spiral of attack and revenge, mistrust and lies, finally failed. The outside interference of hostile 'third forces' and other trans-local networks with vested interests, by no means congruent with the legitimate interests of the local community, and of a quite different nature than those involved in Limpopo Province, proved to be too strong to be handled by the villagers alone. They had to tackle unknown forces brought to their village by its integration into new trans-local social spaces propelled by the forces of globalisation in general, and the transition process from the apartheid regime in particular. Once this Pandora's box had been opened, there was apparently no way out, which could be implemented by the villagers themselves. Their outlook, which appeared bleak, eventually reflected a fundamental shift in their worldview as Jeff Peires (1999)

\footnotetext{
55. 'When there was a problem or someone died, residents would point a finger at someone in the area and claim he had bewitched the deceased and the trouble started from there. I suggest that witchdoctors be called and that they state their position in this regard.' Quoted in: S. Mzimba: 'Community stands together against "We die together", Daily Dispatch 25.05.99. At the time of the meeting, the police claimed to be in the possession of a 'hit list' of people who were still to be eliminated at Jence, allegedly by men associating themselves with Mfelandawonye.

56. See 'Tsolo killers will pay - SAPS', Daily Dispatch 31.05.1999.
} 
suggested. ${ }^{57}$ The provincial and national level police and political administration may not have realised the scope and possibilities of this indigenous peace and reconciliation initiative in time. Greater official recognition and assistance, and the extension of this initiative to the whole province accompanied by a thorough investigation into the linkages of 'third forces', might have solved the problem. But for reasons still to be investigated, the culture of silence at provincial and national level prevailed; the official reaction was rather lukewarm and uncoordinated, and the killings continued, though on a smaller scale ${ }^{58}$

\section{References}

Ashforth, A. 2001. 'AIDS, witchcraft and the problem of power in post-apartheid South Africa', Princeton: Institute of Advanced Study, School of Social Science, Occasional Paper Nr. 10.

Baker, B. 2001. 'Taking the law into their own hands: fighting crime in South Africa', Grenoble: African Studies Centre, Coventry University/ECPR, Occasional Paper

Beinart, W. 1987a. 'Conflict in Qumbu: rural consciousness, ethnicity and violence in the colonial Transkei', in W. Beinart et C. Bundy, eds. Hidden Struggles in Rural South Africa: politics and popular movements in the Transkei and Eastern Cape. London: James Currey, 1987: 106-37.

Beinart, W. 1987b. 'Amefelandawonye (the Die-hards): popular protest and women's movements in Herchel District in the 1920s', in Beinart et Bundy, Hidden Struggles in Rural South Africa: 222-269.

57. See Peires 1999: 14: 'The older generation of anti-thieves were rural people. They regarded society as naturally harmonious and designed their anti-theft campaigns to rectify injustice and restore harmony by means of confession and compensation. The attitudes of Mafelandawonye are shaped by the harsher and more divided universe of the towns and the mine compounds. They see the world as a battleground between good and evil, between Mafelandawonye and the thieves. No neutrality is possible, no middle way. To such a conflict there can be no end.'

58. Awareness campaigns, initiated in July 1999, had, according to Umtata area assistant commissioner Trevor Hayes, already covered more than $80 \%$ of the localities in the area and contributed largely to the visible decrease in related killings. In November 1999 Tabankulu police and community, in one of the region's most notorious areas for stock theft and witchcraft-related faction fighting, received high praise for launching their first community policing forum (CPF) to prevent and combat crime. Hayes once again maintained that poor police-community relations in Tabankulu were now 'water under the bridge' and that 'faction fighting in this area seems to be something of the past as a result of their tireless efforts'. But in February 2000 a Qumbu constable died in a hail of bullets, being attacked by unknown gunmen while walking with his wife at night; this was the second killing of a police officer and the fifth murder in Eastern Cape since the beginning of the year (see Patrick Burnett 'Cop killing continues as Qumbu constable is gunned down', East Cape News 22.02.2000). In October 2002 the police reported more than 500 witchcraft related cases in the Umtata region since January 2001. The hotspots of witchcraft violence shifted to Libode, Mount Frere, Mount Ayliff, Flagstaff, Port St. Johns, and Umzimkulu (see Daily Dispatch 18.10.2002). 
Beinart, W. 1995. ,Chieftaincy and the concept of articulation: South Africa circa 1900-50', in Herchel District in the 1920s', in Beinart \& Bundy, Hidden Struggles: 222-69

Blok, A. 1975. The Mafia of a Sicilian Village: a study of violent peasant entrepreneurs 1860 1960. New York: Harper \& Row.

Campbell, P. J. 2000. 'The Truth and Reconciliation Commission (TRC): human rights and state transitions: the South African model', African Studies Quarterly 4, 3: 1-30.

Commission of Gender Equality (CGE). 1999. The National Conference on Witchcraft Violence. Braamfontain, Conference Report.

Comaroff, J. \& J.L. Comaroff. 1999a. 'Occult economies and the violence of abstraction: notes from the South African postcolony', American Ethnologist 26: 279-303.

Comaroff, J. \& J.L. Comaroff. 1999b. 'Alien-Nation: zombies, immigrants, and millennial capitalism', CODESRIA Bulletin 3\&4: 17-27.

Crais, C. 2002. The Politics of the Evil: magic, state power and the political imagination in South Africa. Cambridge University Press.

Delius, P. 1997. A Lion Amongst the Cattle: reconstruction and resistance in Northern Transvaal. Oxford: James Currey.

Elwert, G., S. Feuchtwang \& D. Neubert, eds. 1998. Dynamics of Violence. Berlin: Duncker \& Humboldt.

Faure, V. 2000. Dynamiques Religieuses en Afrique Australe. Paris: Karthala.

Geschiere, P. 1997. The Modernity of Witchcraft: politics and the occult in postcolonial Africa. Charlottesville, VA and London: University Press of Virginia.

Geschiere, P. 2000. 'Sorcellerie et modernité: retour sur une étrange complicité', Politique Africaine 79: 17-32.

Heald, S. 1999. Manhood and morality: sex, violence and ritual in Gisu society. London: Routledge.

Human Rights Committee (HRC). 1996. Tsolo Battleground. Braamfontein: HRC.

HRC. 1997. Dimensions of Continuing Violence in Tsolo and Qumbu: murder, gun running, stocktheft and intimidation. Braamfontein: HRC.

Hunter-Wilson, M. 1951. 'Witch-beliefs and social structure', American Journal of Sociology, 56: 307-13, reprinted in: M. Marwick, ed. Witchcraft and Sorcery. Harmondsworth: Penguin, 1970: $252-63$

Kessel, I. v. 1993. 'From Confusion to Lusaka: the youth revolt in Sekhukhuneland', Journal of Southern African Studies 19, 4: 593-614. 
Kohnert, D. 1983. 'Indicators of Social and Political Conflict in African Societies: on the articulation of witchcraft among the Nupe, Northern Nigeria.' Working Paper No. 32, Forschungsschwerpunkt Entwicklungssoziologie, Universität Bielefeld.

Kohnert, D. 1988. 'Socialism without liberation: land reclamation projects in Guinea-Bissau', Sociologia Ruralis 2/3: 161-75.

Kohnert, D. 1996. 'Magic and witchcraft: implications for democratization and poverty-alleviating aid in Africa', World Development 24, 8: 1347-55.

Kohnert, D. 2002. 'Occult beliefs, globalization and the quest for development in African societies: the example of South Africa', in G. Mitchell \& E. Mullen, eds. Religion and the Political Imagination in a Changing South Africa. New York: Waxmann, 169-88.

Kuckertz, H. 1990. Creating Order: the image of the homestead in Mpondo social lives. Braamfontein: Witwatersrand University Press.

Lambrecht, I. 2000. 'Cultural artefacts and the oracular trance states of the Sangoma in South Africa', in 'African Art and Rituals of Divination'. New York: Metropolitan Museum of Art. <http://www.metmuseum.org/explore/oracle/essay.html>.

Louw, A. \& M. Shaw 1997. 'Contextualising crime and poverty', in Stolen Opportunities, Monograph No 14. Johannesburg: Institute for Security Studies (ISS). <http://www.iss.co.za/Pubs/Monographs/14/....html >.

Maluleke, T. S. 2001.'Can lions and rabbits reconcile? The South African TRC as an instrument for peace-building', The Ecumenical Review 53, 2: 190-201.

Meyer, B. 1999. Translating the Devil: religion and modernity among the Ewe in Ghana. Trenton, NJ: Africa World Press.

Minnaar, A. 1998. 'Violence in Tsolo and Qumbu (Transkei, 1993-1997): lawlessness, criminality and community conflicts: law and order problems in the Tsolo and Qumbu Districts'. Johannesburg: Institute for Human Rights and Criminal Justice Studies, Occasional Paper No. 3.

Minnaar, A. 1999. 'Witch Purging in the Northern Province of South Africa: a victim profile and assessment of initiative to deal with witchcraft', unpublished paper, Witchcraft Summit, Giyani, 28 September 1999.

Minnaar, A., D. Offringa \& C. Payze. 1991. 'The witches of Venda: politics in magic potions', Indicator SA 9, 1: 53-6.

Ngwane, A., V. Yadavalli \& F. Steffens. 2001. 'Poverty in South Africa: a statistical analysis', Development Southern Africa 18, 2: 201-16.

Niehaus, I.A. 1998. 'The ANC's dilemma: the symbolic politics of three witch-hunts in the South African lowveld, 1990-1995', African Studies Review 41, 3: 93-118.

Niehaus, I.A., E. Mohlala \& K. Shokane 2000. Witchcraft, Power and Politics: exploring the occult in the South African lowveld. London: Pluto Press. 
Niehaus, I. A. 2002a. 'Perversions of power: witchcraft and the sexuality of evil in the South African lowveld'. Journal of Religion in Africa, 32, 3 (in press)

Niehaus, I.A. 2002. 'Witchcraft in the new South Africa: from colonial superstition to postcolonial reality?', in H.L. Moore \& T. Sanders, eds. Magical Interpretations, Material Realities: modernity, witchcraft and the occult in postcolonial Africa. London: Routledge, 184-205.

Peires, J. B. 1992. 'The implosion of Transkei and Ciskei', African Affairs 91, 364: 365-87

Peires, J. B. 1994. 'Unsocial bandits: the stock thieves of Qumbu and their enemies', unpublished paper, University of Witwatersrand History Workshop, 13-15 July 1994.

Peires, J.B. 1999. 'Secrecy and violence in rural Tsolo', unpublished paper, South African Historical Association Conference, University of Western Cape, July 1999.

Peires, J.B. 2000: 'Traditional leaders in purgatory: local government in Tsolo, Qumbu and Port St. Johns, 1990-2000', African Studies 59, 1: 97-114

Pels, P. 1998. 'The magic of Africa: reflections on a Western commonplace', African Studies Review 41, 3: 193-209.

Pries, L. 1999. 'Transnational social spaces: do we need a new approach in response to new phenomena?', in L. Pries. ed. 2001. New Transnational Social Spaces. London: Routledge.

Ralushai, N.V. et al. 1996. Report of the commission of inquiry into witchcraft violence and ritual murders in the Northern Province of the Republic of South Africa. Unpublished.

Redding, S. 1996. 'Sorcery and sovereignty: taxation, witchcraft, and political symbols in the 1880 Transkei rebellion', Journal of Southern African Studies 22, 2: 249-70.

Redding, S. 1996b. 'Government witchcraft: taxation, the supernatural, and the Mpondo revolt in the Transkei, South Africa, 1955-63', African Affairs 95, 381: 555-79.

Sassen, S. 1999. 'Cracked casings: notes towards an analytics for studying transnational processes', in L. Pries, ed. 2001. New Transnational Social Spaces. London: Routledge.

Schärf, W. 2001. 'Community justice and community policing in post-apartheid South Africa', IDS Bulletin 32, 1: 74-81.

Stadler, J. 1996. 'Witches and witch-hunters, witchcraft generational relations, and the life-cycle in a Lowveld village' African Studies 55, 1: 87-110.

Stanley, E. 2001. 'Evaluating the Truth and Reconciliation Commission', Journal of Modern African Studies 39, 3: 525-46.

Wiles, J. 2002. 'An African Renaissance of occult cosmology? On the continuity and divide of traditional belief systems in South Africa', in G. Mitchell \& E. Mullen, eds. Religion and the Political Imagination in a Changing South Africa. New York: Waxmann, 189-206. 
Newspapers and News Agencies

African Eye News Service, Nelspruit; ANC News, Cape Town; Business Day, Johannesburg; Cape Argus, Cape Town; Daily Dispatch, East London, online edition at <http.//www.dispatch.co.za>; East Cape News, Grahamstown; Mail \& Guardian, Johannesburg; South African Press Association PR wire service. 